\title{
Policy Analysis for Ehealth in Denmark
}

Morten Benneke $^{1}$, George Charalambous ${ }^{2}$, Olaf Jensen ${ }^{1}$ and Debbie Andrioti ${ }^{{ }^{*}}$

${ }^{1}$ Centre of Maritime Health and Society, Department of Public Health, University of Southern Denmark, DK-6700, Esbjerg, Denmark ${ }^{2}$ Hippokration Hospital, Coordinator MSc in Health Management, Frederick University Cyprus, Limassol 3080, Cyprus

\begin{abstract}
Background: Ehealth is an innovative solution to provide prevention and health care services at a distance. It contributes to the effectiveness of the health systems in times of workforce shortages and scarcity of resources and helps the patients to self-manage their disease. The aim of this article was the analysis for policy in Denmark.
\end{abstract}

Methods: A literature review was conducted in PubMed, Cinahl and Google Scholar using the keywords between September and November 2017. We applied the policy triangle framework, to identifying the relevant actors, context, content and process, coupled with the stages heuristic and the Hall model to assess the levels of legitimacy, feasibility, support for the policy as well as and the Kingdon's model to assess the three streams of policy process, problem, policy and politics that create a window of opportunity in agenda setting.

Results: Applying the policy triangle framework for policy, showed that context included the demographic changes, the welfare state and the public demands of the welfare state. Actors in this policy were mainly governmental at national-, regional- and local level, but also patient organizations and health professionals. Content concerned with the establishment of knowledge base, creation of standards for telehealth use, patient independence and health promotion. The process showed that ehealth reached the political agenda by having legitimacy, feasibility and support. Implementation in the 5 kick-offs areas consisted of several pilot tests, operations phases and ongoing evaluation.

Conclusion: Even though a policy window was present in the country leading to the establishment of innovative solutions in the health sector, the different players/actors with various levels of power contributed to the fragmentation of the telehealth system. Policy makers should redefine the system in favor of the patients, the health professionals and the economy.

\section{Introduction}

Demographic changes, personal lifestyles and health workforce shortages are increasing the pressure on policy makers in many sectors. Especially the increase in the elderly population is predicted to continue for many years to come [1]. According to Statistics Denmark, predictions showed that the number of people age 70 years and older in Denmark will keep increasing until year 2040 [2]. Increased life expectancy coupled with personal life styles may lead to an increased risk for developing non-communicable diseases such as diabetes, chronic obstructive pulmonary disease, cardio vascular diseases and mental health issues [3]. Increase in non-communicable diseases will bring an increase in demand for care resulting in higher expenditure in the healthcare sector.

It is estimated that non-communicable diseases account for 70-80 $\%$ of all expenditures, equivalent to about 145 billion DKK, in the Danish health system [4]. The increasing demand for long-term care for patients with non-communicable diseases, is projected for all OECD countries to almost double the amount of GDP spent on longterm care, from around $7 \%$ in 2005 to around $13 \%$ in 2050, while others predict a smaller increase from $1 \%$ to around $2-4 \%[3,5]$.

Furthermore, the amount of family care (where family members take care of the patient) is also expected to decrease over the years, as more and more people will be living alone and thereby increasing the demand for formal care further [1]. This creates uncertainty on the future demand for care. Dependency among the patients and future cost of delivering care are also some factors that create uncertainty [1].

With increasing demand for care, supply should increase as well. However, labor force projection showed that Denmark will have an average annual growth in total labor force of $-0.4 \%$ in the period of 2005-2025 and $-0.3 \%$ in 2025-2050 [6]. In 2011, OECD projected that the costs of long-term care will increase higher than the average wage level, and thereby it will also create a labor shortage in the health sector [1].

International Organizations including WHO and European Union presented telehealth as a way of accomodating the increasing demand for care. Telehealth (telemedicine, ehealth, mhealth) refer in a broad sense to the communication between the health professional and the patient (client) via the internet with a purpose to provide a range of health services including prevention and education, self-disease management by the patient as well as care at a distance through voice, video, monitoring and messaging communication [3]. It enables health professionals and care givers to provide services to the patients without the patients need to leave their home or the health workers to leave their workplace [3]. It eases cross sectional coordination and effectuate the care supplied allowing the health worker to gain instant access, among others, to patients' journals, scanning results and pharmaceuticals, achieving cost savings to the care sector [3]. The European Commission's science and knowledge service, Joint Research Centre, stated in 2011 that Denmark was one of the leading

*Corresponding Author: Dr. Debbie Andrioti, Centre of Maritime Health and Society, Department of Public Health, University of Southern Denmark Niels Bohrsvej 9-10, DK-6700, Esbjerg, Denmark, Tel + 456550 9391; Email: dandrioti@health.sdu.dk

Citation: Benneke M, Charalambous G, Jensen O, Andrioti D (2018) Policy Analysis for Ehealth in Denmark. Int J Community Fam Med 3: 140. https://doi. org/10.15344/2456-3498/2018/140

Copyright: (c) 2018 Benneke et al. This is an open-access article distributed under the terms of the Creative Commons Attribution License, which permits unrestricted use, distribution, and reproduction in any medium, provided the original author and source are credited. 
countries in Europe to do research and deployment of telehealth $[7,8]$. In 2012 the Danish Government formulated a national strategy for the dissemination of telehealth (telehealth, ehealth and telemedicine are referring to the same concept in the national strategy) in the country [7]. The following year the Local Government Denmark, presented their version of the strategy on how to incorporate telehealth into the local health sector [9]. The purpose was to provide high quality of services to the whole population, increase access to care, and increase health professionals' competencies using information and communication technologies as effective innovative ways for the provision of these services. Early attempts to this direction started in the begging of 2000 with the registration of patients' electronic records.

\section{Administration and health system organization}

The political system in Denmark is decentralized (the same applies to the health sector) in three levels: the state, the five regions and 98 municipalities. The state initiates, coordinates and advises on national health policy with the Ministry of Health being responsible for designing the national policy and the legislation in health care. Regions and municipalities are in charge of providing health services to the whole population at regional and local level respectively.

The health system is taxed financed, covers the whole population and the services are provided free of charge. It is well known as the Scandinavian model. In 2012, the public expenditures amounted to $84 \%$ of total health expenditures.

This article aims at analyzing the policy for ehealth using policy models.

\section{Methods}

\section{Data collection}

The study was a literature review. Literature search was conducted through PubMed, Cinahl and Google Scholar. Articles where first selected based on their titles and further selection was based on their abstracts, language either in English or Danish, during SeptemberNovember 2017. Search terms were: tele-health, telecare, telemedicine, ehealth, care, evaluation, effectiveness and quality.

Furthermore, data from WHO, EU, OECD, the Ministries, the Regions and the Local Government Denmark, were collected through their respective websites regarding the topic of telehealth. Chain search from included articles was also made, through studying reference lists of the included articles.

\section{Theoretical framework}

The results were analyzed using the policy triangle frame work developed by Gill Walt and Lucy Gilson in 1994. The policy triangle consists of four factors which should be considered when analyzing policies: content, context, process and actors (Figure 1) [10].

Briefly presenting the model one should point out its main components:

Content refers to what the policy is all about, its objectives, aims, value and impact. It is the substance of the policy and it explains

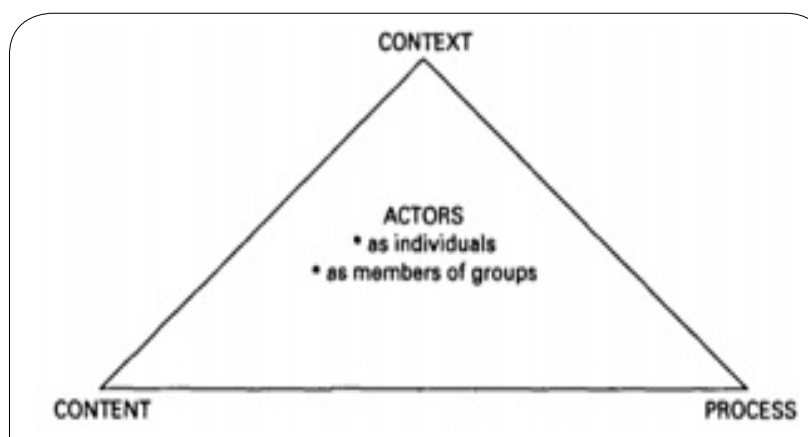

Figure 1: A model for health policy analysis.

\begin{tabular}{|l|l|}
\hline $\begin{array}{l}\text { Situational } \\
\text { factors }\end{array}$ & $\begin{array}{l}\text { A non-permanent or temporary event that has an } \\
\text { impact on the policy, including change of govern- } \\
\text { ment, natural disaster and workers strike }\end{array}$ \\
\hline $\begin{array}{l}\text { Structural } \\
\text { factors }\end{array}$ & $\begin{array}{l}\text { Relatively unchanging parts in the society such as } \\
\text { the political system, demographic structure, and the } \\
\text { economy. These factors are more predictable. }\end{array}$ \\
\hline Cultural factors & $\begin{array}{l}\text { Values and beliefs of the whole society orminori- } \\
\text { ties, including religious and/or ethic and vulnerable } \\
\text { groups, as well as gender differences }\end{array}$ \\
\hline $\begin{array}{l}\text { International/ } \\
\text { Environmental } \\
\text { factors }\end{array}$ & $\begin{array}{l}\text { Events, values, conditions that exist outside the } \\
\text { boundaries of the political system of the country i.e } \\
\text { If the topic is high on the agenda of international/ } \\
\text { multinational organizations, including WHO and EU. }\end{array}$ \\
\hline
\end{tabular}

which areas are going to affect, how and by whom. Context refers to all the systemic factors that can impact the policy. Leichter (1979) developed a way of dividing the systemic factors into four categories [12], described in Table 1.

Actors are all those involved and/or can affect the decision making of the policy. These can reside at local-, regional-, national- or international level. They can be groups, individuals or organizations, along with being governmental, private, and volunteer or other interested groups. In addition, it implies the amount of power and interest each actor has over the decision making [13].

The process can be described through the stages heuristics/ policy cycle or policy phase model, first presented by Sabatier and JenkinsSmith [14] and adapted by Buse et. al [13], containing the following four steps:

\section{Problem identification}

The topic reaches the political agenda. For telehealth to reach the political agenda and even being considered, it must go through the process of agenda setting, to achieve a higher priority than other "everyday" political issues [13]. Regarding agenda setting in the process factor, Phoebe Hall (1975) developed a model explaining how an item could reach the political agenda. More specifically she pointed out that for an issue to reach the political agenda, three fundamental aspects are needed: legitimacy, feasibility and support [11]. Legitimacy is achieved when the policy makers have an incentive or are obliged to act upon the issue. Feasibility refers to the existence of a practical solution and if the policy makers have enough theoretical and technical knowledge, resources and administrative abilities to respond. Finally, support refers to the support showed by the public for the issue depending on the political system. Furthermore, 
Kington (1984) in his model argued that there should be a window of opportunity of agenda setting and this happens only when, the three streams- the problem stream, the politics stream and the policy stream run together allowing the item to move onto the governments' formal agenda.

\section{Policy formulation}

Clarification of who are involved in making the policy and how it is agreed upon and communicated. It includes the actors identified by the policy triangle.

\section{Policy implementation}

What is done to implement the policy and what is the expected impact of the policy. This is the more important phase, since if the policy is not implemented, then the work done is wasted.

\section{Policy evaluation/feedback}

Is a comparison between the goals set and the achievements or the gaps identified in relation to the objectives. It can also be used to identify areas that need optimization, and it usually takes place after the implementation phase.

The stages heuristics model, should not be perceived as a linear approach for policy making. It should rather be perceived as an ongoing circular process [13].

\section{Results}

\section{Context}

The situational factors consist of the above mentioned increase in the elderly population, along with the increase of patients with NCD, the relevant costs and predicted workforce shortages. The structural factors lie within the welfare state of Denmark. An egalitarian ideology, based upon universalism and public participation in areas such welfare, which ensures promotion of equity through social benefits and policies and a high amount of GDP spent on social and health policies.

Funding of the health and social sectors, as already mentioned are done through taxes ensuring somewhat adequate funding [15] for the society as a whole taking care of the most vulnerable groups.

The cultural factors derive from the welfare state. The Danes have high demands for the services provided by the health sector and beliefs are that people spent their life, paying for the health sector through taxes and thus have a "right" to get the best treatment and care free of charge at the point of need [15]. The international factor is that WHO and EU put telehealth high on their agenda and thus encouraging nations to consider electronic technologies solution by sharing ideas and research [3].

\section{Actors}

The main actors of the strategy for implementing telehealth was the Government via the respective Ministries, Local Government Denmark (98 municipalities) and the Danish Regions (5 Regions). The common denominator for these actors is that they have great power [16]. More specifically the two decentralized entities have the power to uphold the laws and regulations that have been put forward by the Parliament. Usually all the laws and regulation formulated by the government will be pass, however there isn't always agreement between the central and the local governments which have the responsibility of the policy implementation. The political power of the Regions derives from the large numbers of health professionals as part of the primary and secondary care in their payrolls and the administration of the respective health and welfare budget while the Local Governments (municipalities) are responsible for implementing prevention strategies and the social agenda at local level [24,25].

In addition, there are other important actors including the Danish Agency for Digitization, an agency under the Ministry of Finance, which means this has high power and it is responsible for the digitization of the public sector and the implementation of welfare technology [18]. Another actor was the National Health-IT, an agency under the Ministry of Health and Prevention, which give them high power and have the same task as the former albeit targeting the health sector $[19,20]$.

At regional and local level, other actors were: the Region's HealthIT, which have the same tasks as the National Health-IT, however they are a subgroup for the Danish Regions and only work at a regional level [21]. This gave them high regional power, but less power at the national level.

\begin{tabular}{|c|c|}
\hline Main goals & Sub goals \\
\hline \multirow{3}{*}{$\begin{array}{l}\text { Create reference } \\
\text { architecture and } \\
\text { standards for use of } \\
\text { telehealth }\end{array}$} & $\begin{array}{l}\text { Determine frames for collection of pa- } \\
\text { tients' health data through gathering, } \\
\text { communication and storage }\end{array}$ \\
\hline & $\begin{array}{l}\text { Provide frames for sharing of documents } \\
\text { and pictures }\end{array}$ \\
\hline & $\begin{array}{l}\text { Create "packages" to ensure common } \\
\text { ter-minology, services and health workers } \\
\text { performance }\end{array}$ \\
\hline \multirow{3}{*}{$\begin{array}{l}\text { Balanced evidence } \\
\text { need }\end{array}$} & Create and share uniform knowledge base \\
\hline & Increased use of telehealth \\
\hline & Make health technology assessment \\
\hline \multirow{2}{*}{$\begin{array}{l}\text { National overview } \\
\text { of the use of } \\
\text { telehealth }\end{array}$} & -Annual reports published \\
\hline & $\begin{array}{l}\text { Collect data from international use of tele- } \\
\text { health for comparison and development }\end{array}$ \\
\hline \multirow{2}{*}{$\begin{array}{l}\text { Encourage patients } \\
\text { to continue } \\
\text { everyday life with } \\
\text { their disease/ } \\
\text { disability }\end{array}$} & Give independence, trust and safety \\
\hline & $\begin{array}{l}\text { Support prevention, treatment and reha- } \\
\text { bilitation at patients' homes }\end{array}$ \\
\hline \multirow{2}{*}{$\begin{array}{l}\text { Support health } \\
\text { promotion and } \\
\text { prevention by } \\
\text { motivating and } \\
\text { maintain healthy } \\
\text { lifestyles }\end{array}$} & $\begin{array}{l}\text { Early diagnosis for patients with high risk of } \\
\text { non-communicable diseases }\end{array}$ \\
\hline & $\begin{array}{l}\text { Through health education to make tar-geted } \\
\text { health communication to patients, doctors } \\
\text { and health workers }\end{array}$ \\
\hline \multirow{3}{*}{$\begin{array}{l}\text { As a minimum, } \\
\text { provide the same } \\
\text { quality of care } \\
\text { as traditional } \\
\text { methods and be at } \\
\text { least as efficient }\end{array}$} & $\begin{array}{l}\text { Include newly diagnosed non- } \\
\text { communicable diseases patients }\end{array}$ \\
\hline & $\begin{array}{l}\text { Disease management protocols and } \\
\text { guidelines }\end{array}$ \\
\hline & Improved continuity of care \\
\hline
\end{tabular}


Citation: Benneke M, Charalambous G, Jensen O, Andrioti D (2018) Policy Analysis for Ehealth in Denmark. Int J Community Fam Med 3: 140. https://doi. org/10.15344/2456-3498/2018/140

Page 4 of 6

Furthermore, there was MedCom, a non-profit organization owned and financed by the Ministry of Health, local government Denmark and the Danish Regions that was also a part of the policy. They serve as a link between governmental actors and public actors to develop digital communication solutions to the health sector [22]. They consist of a mix of public and private actors and they are evaluated by a central authority [23].

\begin{tabular}{|c|c|}
\hline \multirow{11}{*}{$\begin{array}{l}\text { Integrated home } \\
\text { monitoring } \\
\text { for the elderly } \\
\text { population }\end{array}$} & Initiation of project \\
\hline & Baseline measuring \\
\hline & Pilot testing and technical preparation \\
\hline & Education in telehealth of health workers \\
\hline & First operation phase \\
\hline & First mid-term evaluation \\
\hline & Second operation phase \\
\hline & Third operation phase \\
\hline & Outcomes measurements \\
\hline & Evaluation of sub-projects \\
\hline & Reporting and dissemination \\
\hline \multirow{4}{*}{$\begin{array}{l}\text { Home } \\
\text { monitoring of } \\
\text { patients with } \\
\text { COPD }\end{array}$} & Resolution and drafting of business case \\
\hline & Clarification, specification and development \\
\hline & Implementation and testing \\
\hline & Ongoing initialization and evaluation \\
\hline \multirow[t]{8}{*}{$\begin{array}{l}\text { Diabetic foot- } \\
\text { ulcer assessment }\end{array}$} & $\begin{array}{l}\text {-Appointment of project manager and steering } \\
\text { com-mittee }\end{array}$ \\
\hline & Municipal specific plan for telehealth in place \\
\hline & $\begin{array}{l}\text { Conclude cooperation agreements with hospital } \\
\text { wards }\end{array}$ \\
\hline & Seek support in health agreements \\
\hline & Procurement of additional equipment \\
\hline & Education of health workers \\
\hline & Initialization and recruitment of patients \\
\hline & Data collection and evaluation \\
\hline \multirow{9}{*}{$\begin{array}{l}\text { Tele psychiatry } \\
\text { and e-mental } \\
\text { health }\end{array}$} & Initiation of project \\
\hline & Minor pilot tests \\
\hline & Evaluation of pilot tests \\
\hline & $\begin{array}{l}\text { Dissemination of cooperation among psychiatric } \\
\text { units }\end{array}$ \\
\hline & $\begin{array}{l}\text { Cooperation agreement with municipal } \\
\text { psychiatric units }\end{array}$ \\
\hline & Technical preparation \\
\hline & Education of health workers \\
\hline & Final pilot tests \\
\hline & Evaluation \\
\hline \multirow{6}{*}{$\begin{array}{l}\text { Internet } \\
\text { psychiatry }\end{array}$} & Application for funding \\
\hline & Approval of application \\
\hline & Development phase \\
\hline & Operation phase \\
\hline & Collection of data and evaluation \\
\hline & Transition to ordinary operation \\
\hline
\end{tabular}

Table 3: Policy implementation on the five chosen areas.
Moreover, the Danish Patients is an interest group, representing the patients and patient organizations. They aim to ensure evidence based treatment and care and open dialogue in policy making in favor of their members [26]. They have very high interest, since they work for the best treatment and care for the patients. They pose high intangible power, when it comes to local, regional and central elections.

Additional important actors were the health professionals via their associations, who should support the policy and are responsible for the implementation of policy.

The relevant ehealth policy as to the components is described in Tables 2 and 3 .

\section{Content}

The main objectives of implementing telehealth is to reduce the costs of care and make care better and more efficient [7] are presented in Table 2.

The goals are expected to bring more cross sectoral cooperation and competency development among the health workers and achieve a better quality of care. There are several examples of ehealth policies around the country. Here we describe the five kick-off areas [7]:

1. Integrated home monitoring

2. Home monitoring of patients with chronic obstructive pulmonary disease

3. Diabetic foot-ulcer assessment

4. Telepsychiatry and e-mental health

5. Internet psychiatry

\section{Process}

The problem identification consists of telehealth reaching the political agenda. It achieved legitimacy through the increase in health expenditure, as described earlier. This requested the government calling up for a solution. Feasibility was achieved through research in telehealth which gave the government both theoretical and practical knowledge $[7,8]$. Support was indirectly gained through the public demand for better care, integrated in a welfare system [15]. The policy formulation was made by the working group responsible of the national strategy, clarified in the "Actors." Policy implementation on each of the five areas for telehealth can be seen in Table 3. The implementation in all five areas was planned to take place between November 2011 until December 2014 [7].

Policy evaluation is included in the implementation plan in all five areas. The evaluation covered outcome measurement and economic evaluations and usually takes places after the implementation phase [7].

\section{Discussion}

Traditional care includes physical presence and proximity between patients and caretakers [27]. Caretakers adjust their services according to information provided by their patients and their health records. This facilitate personalized care [27]. Ehealth, brings challenges to care since caretakers must develop new ways to perceive these factors to provide similar quality of care at a distance [27-29]. Lack of human touch and nonverbal communication, will bring challenges 
Citation: Benneke M, Charalambous G, Jensen O, Andrioti D (2018) Policy Analysis for Ehealth in Denmark. Int J Community Fam Med 3: 140. https://doi. org/10.15344/2456-3498/2018/140

Page 5 of 6

to caretakers and their relation to the patients as personal empathy and compassion will be lacking [27]. Telehealth, in a sense, also challenges the holistic approach of patients, as the patients are served at a distance.

Furthermore, it can be argued that it encourages isolation. This might be an important issue especially for the elderly population, who should learn new ways of communication and use the new technologies as well $[27,30]$.

One major topic regarding implementation of telehealth, is whether it is more effective compared to traditional care and comes with lower costs. In the national strategy, the five areas of implementation were shown to generate profit within 3-5 years, except for home monitoring which showed mixed results [7]. Home care through video and specialist consulting seemed to be cost-effective, whereas local delivery of care services between hospital and primary care were not found cost-effective [31]. Digital diabetic foot ulcer assessment were as effective as traditional, however economic benefits were hard to assess [32]. Telehealth use for patients with COPD, showed uncertainty concerning cost-effectiveness [33]. Especially measurement of benefits seemed to be inconsistent in various studies, which might explain differences in conclusion about whether telehealth is costeffective in several settings [34]. However, telehealth for patients with chronic obstructive pulmonary disease is shown to reduce hospital admissions from 1.17 per 10 months to 0.48 per 10 months, as well as telehealth patients achieved longer time until admittance [35]. Furthermore, the admission costs decreased from $4576 €$ to $3461 €$ [35]. The innovative ehealth solutions are powerful tools as they can help the seafarers, fishermen, offshore employees and the mobile workers in general, to have their health data at hand. It helps medical doctors in relation to the accurate diagnosis and disease management, while in addition, prevents the duplication of exams and thus decrease the related costs.

\section{Conclusion}

The Danish government and the rest of stake holders for the national strategy of telehealth, seem to have focused a lot on the technical aspects of telehealth and the more tangible benefits of it, like shorter waiting lists, costs savings and more efficient care. However, they seem not to address the needs of health workforce and the patient side of the case. In this regard the administrative and academic staff may not have sufficient understanding of the system while the patients are being dissociated from human-to-human contact and proximity, which might lead to a difference in the care given. One major limitation is conflicting evidence of the cost effectiveness of using telehealth in integrated care due to lack of clear guidelines in relation to its evaluation. This creates uncertainty on return of investment for the policy makers if they choose to look at all evidence and not cherry-picking the positive ones. To uncover the true potential and effectiveness of telehealth, researchers need to create consensus on how to evaluate telehealth. Furthermore, the stakeholders with various range of power created a fragmented system. There is not always communication among the different IT systems contributing to a level of ineffectiveness. As an example, the system of health emergencies at sea does not communicate with patient's records and the respective maritime authorities. Thus, medical doctors lack a clear picture of the patient's health state making it difficult to provide timely and effective services. Stakeholders should work to increase the systems cooperation for the benefit of the population, the health professionals and the society. In addition, they should address the lack of competencies of administrative and health professionals by

\section{Author Contributions}

$\mathrm{MB}$ carried out the data gathering and policy analyses as well as drafted the initial manuscript. GC substantially contributed to the interpretation of the data and provided comments on all drafts. DA and OCJ designed the study, contributed to the interpretation of the data and provided comments on all drafts. All authors confirm that this manuscript describes original work and has neither been published or submitted for publication elsewhere. All authors read and approved the final manuscript.

\section{References}

1. Colombo F (2011) Help Wanted? Providing and Paying for Long-Term Care. Paris: OECD Publishing.

2. Klintefelt AME (2017) Befolkningsfremskrivning Denmark. Danmarks Statistik.

3. World Health Organization (2010) How Can Telehealth Help in the Provision of Integrated Care? World Health Organization.

4. Morgen M (2011) Kommuner og kronikere : bedre pleje og behandling eget hjem. Kbh Kgs Lyngby: Mandag Morgen, Tryghedsgruppen.

5. Organization for Economic Cooperation and Development (2006) Projecting OECD Health and Long-term Care Expenditures. What Are the Main Drivers?

6. Burniaux J, Duval R, Jaumotte F (2004) Coping with Ageing. OECD Publishing.

7. Danske Regioner, Kommunernes Landsforening, Ministeriet for Sundhed og Forebyggelse, Social- og Integrationsministeriet, Erhvervs- og Vækstministeriet, et al. (2012) National handlingsplan for udbredelse af telemedicin. Denmark.

8. Abadie F, Codagaone C, Lieshout M, Pascu C, Baum P et al. (2010) Strategic Intelligence Monitor on Personal Health Systems (SIMPHS): Market Structure and Innovation Dynamics. Publications Office of the European Union.

9. Landsforening K (2013) Kommunernes strategi for telesundhed. KL.

10. Walt G, Gilson L (1994) Reforming the health sector in developing countries: the central role of policy analysis. Health policy and planning 9: 353-370.

11. Hall $P$ (1975) Change, choice, and conflict in social policy. Heinemann Educational Books.

12. Leichter HM (1979) A comparative approach to policy analysis: health care policy in four nations. CUP Archive.

13. Buse K, Mays N, Walt G (2012) Making health policy. 2 ed. Maidenhead. Open University Press.

14. Jenkins-Smith HC, Sabatier PA (1993) The dynamics of policy-oriented learning. Policy change and learning: An advocacy coalition approach.

15. Magnussen J, Vrangbaek K, Saltman R (2009) Nordic Health Care Systems: Recent Reforms And Current Policy Challenges. McGraw-Hill Education (UK).

16. Folketinget (2017) Sådan arbejder regeringen Denmark. Folketinget. .

17. Folketinget (2017) Lovgivningsprocessen i Folketinget Denmark. Folketinget.

18. Digitaliseringsstyrelsen (2017) Om Digitaliseringsstyrelsen Denmark. Digitaliseringsstyrelsen.

19. Sundheds- og ÆEldreministeriet (2016) Sundheds-it Denmark. Sundhedsog ældreministeret.

20. Sundhedsdatastyrelsen (2017) Om Sundhedsdatastyrelsen

21. Rose R (2017) Regioners Sundheds-it (RSI) Denmark. Danske Regioner.

22. MedCom (2017) Om MedCom Denmark: MedCom

23. MedCom (2017) Organisation Denmark. MedCom.

24. Schults-Jakobsen S (2017) om KL Denmark: Kommunernes Landsforening.

25. Fischer NS (2017) Om de fem regioner Denmark. Danske Regioner.

26. Patienter D (2017) Mission og kerneværdier Denmark. Dankse Patienter. 
Citation: Benneke M, Charalambous G, Jensen O, Andrioti D (2018) Policy Analysis for Ehealth in Denmark. Int J Community Fam Med 3: 140. https://doi. org/10.15344/2456-3498/2018/140

Page 6 of 6

27. Nagel DA, Pomerleau SG, Penner JL (2013) Knowing, caring, and telehealth technology: "going the distance" in nursing practice. Journal of holistic nursing 31: 104-112.

28. Pols J (2010) The heart of the matter. About good nursing and telecare. Health care analysis 18: 374-388.

29. Reierson IÅ, Solli H, Bjørk IT (2015) Nursing Students' Perspectives on Telenursing in Patient Care After Simulation. Clinical Simulation in Nursing 11: 244-250.

30. Zwijsen SA, Niemeijer AR, Hertogh CM (2011) Ethics of using assistive technology in the care for community-dwelling elderly people: an overview of the literature. Aging \& mental health 15: 419-427.

31. Wade VA, Karnon J, Elshaug AG, Hiller JE (2010) A systematic review of economic analyses of telehealth services using real time video communication. BMC Health Services Research 10: 233.

32. Singh TP, Vangaveti VN, Kennedy RL, Malabu UH (2016) Role of telehealth in diabetic foot ulcer management - A systematic review. The Australian journal of rural health 24: 224-229.

33. Udsen FW, Hejlesen O, Ehlers LH (2014) A systematic review of the cost and cost-effectiveness of telehealth for patients suffering from chronic obstructive pulmonary disease. Journal of telemedicine and telecare 20 : 212-220.

34. Bergmo TS (2014) Using QALYs in telehealth evaluations: a systematic review of methodology and transparency. BMC Health Services Research 14: 332.

35. Dinesen B, Haesum LK, Soerensen N, Nielsen C, Grann O, et al. (2012) Using preventive home monitoring to reduce hospital admission rates and reduce costs: a case study of telehealth among chronic obstructive pulmonary disease patients. Journal of telemedicine and telecare 18: 221 225 . 